by-products of industries worth three orders of magnitude more).

That is why Bush's line, for all its apparent reasonableness, smacks of humbug. The urgent question is not so much to know what will be the future course of the Earth's surface temperature if things continue as at present, but to come to grips with the problems that will arise if it is necessary to restrict the emission of all greenhouse gases. Even CFCs are not a simple problem. (China, for one, has not signed the Montreal Protocol.) The difficulties of restricting the emission of carbon dioxide would be three orders of magnitude greater - and will be intrinsically international. The cost may be so great that US taxpayers discover that they cannot afford both compliance and the goal of keeping Los Angeles (and a dozen other cities) free from smog, as required by the Senate's version of the Clean Air Bill that Bush praised last week. (Piquantly, the Senate bill, likely to be echoed by the House of Representatives, requires that gasoline should in future contain a proportion of alcohol derived from corn, which could accentuate the greenhouse effect if more fertilizer means more methane.) The negotiation of international quotas will be a much more serious problem.

That is why the negotiation of a draft convention on greenhouse gases should be the first task of governments. Bush said last week, in his second speech, that the United States will "encourage a convention". Can it not do more than that? Why not "insist on" a convention, even "demand" one? To be sure, as things are, the only appropriate convention there could be would be a document in which the vital numbers defining the points at which various restrictions come into play are left blank, to be filled in later. But that is not a fatal objection. While there are serious problems of equity to be decided, notably those between rich and poor countries, the process of negotiation is likely to take far longer than for research programmes now under way to sharpen estimates of future surface temperature to the point at which they are convincing.

\section{To European unity?}

French and German zeal for a united Europe should prudently concentrate on institution-building.

THE late Sir Winston Churchill's futile day-trip to Paris in 1940 to offer the then-defeated French government political union with the offshore islands to the north was a quixotic gesture born of a sense of danger. So, too, is the declaration last week by President François Mitterrand of France and Chancellor Helmut Kohl of West Germany. What they say is that the time has come to accelerate the pace of change towards political unity within the framework of the European Communities, citing 1993 as a target date. The panic stems from French disquiet about the impending Anschluss of the two parts of Germany. The content of the declaration is a measure of German 798 eagerness to reassure. But, by making light of serious issues staring European people in the face, the dash for unity by 1993 cheapens much of what has been accomplished in Europe in the past three decades and belittles much of what lies in store.

The most serious error underlying the Mitterrand-Kohl declaration is its citation of recent changes in Eastern Europe as the chief impetus for political union within the framework of the European Communities. The same changes might just as well have been taken as the occasion for delay. Why, it might reasonably be asked, settle now for politically united European Communities when the future relationship remains to be determined between the 12 self-satisfied members and the half-a-dozen countries of Eastern Europe (counting is difficult because of the impending Anschluss and because Yugoslavia may count for six), not to mention Scandinavia and even Soviet republics such as Lithuania?

The ideal would be a pan-European security agreement within the framework of the Helsinki agreements of 1978. Some hint of the way that wind can be made to blow should emerge from the European Security Conference at Vienna in June. Decisions such as that of the United States to abandon the improvement of the short-range Lance nuclear missile should help. But only after Vienna will it be feasible to talk of common defence policies and armed forces for the European Communities, as Mitterrand and Kohl were doing last week. The difficulty for the European Communities is that the body is a customs union which hopes to be a single economic market three years from now, but which for the time being lacks both the machinery of unified government and the will to create it.

But all is not lost for Mitterrand and Kohl. The problems and opportunities presented to Western Europe by the changes to the East are more interesting than what would have to be, for now, a paper declaration of unity. Take, for example, Eastern Europe's vast investment in scholarship and research, hamstrung though it is by bureaucracy and the lack of funds (see Nature 344, 599-620; 12 April 1990). Given impending economic upheavals in the East, there is a danger that the investment will be largely wasted. How should Western Europe respond to that prospect?

The simple answer is that while Western university and research systems remain nationally idiosyncratic, they will make the deals that suit them individually with similar institutions in the East. Nobody in the West would now have it otherwise. But if the process of Western integration had gone further, it would have been possible to give the present process of partnership with the East a greater sense of coherence. And many good projects and institutions would be helped in ways that now seem unlikely to materialize. Yet the European Commission does not have legal authority to intervene in higher education and research, and may not be the most appropriate body to do the job. But if not, what else? Those are the questions on which enthusiasts for European unity should seek to cut their teeth. 